\title{
Front Matter: Volume 7869
}

, "Front Matter: Volume 7869," Proc. SPIE 7869, Computer Vision and Image Analysis of Art II, 786901 (20 April 2011); doi: 10.1117/12.888808

Event: IS\&T/SPIE Electronic Imaging, 2011, San Francisco Airport, California, United States 


\section{PROCEEDINGS \\ IS\&T / SPIE \\ Electronic \\ Imaging \\ SCIENCE AND TECHNOLOGY}

\section{Computer Vision and Image Analysis of Art II}

David G. Stork

Jim Coddington

Anna Bentkowska-Kafel

Editors

25-26 January 2011

San Francisco, California, United States

Sponsored and Published by

IS\&T-The Society for Imaging Science and Technology

SPIE

Volume 7869 
The papers included in this volume were part of the technical conference cited on the cover and title page. Papers were selected and subject to review by the editors and conference program committee. Some conference presentations may not be available for publication. The papers published in these proceedings reflect the work and thoughts of the authors and are published herein as submitted. The publisher is not responsible for the validity of the information or for any outcomes resulting from reliance thereon.

Please use the following format to cite material from this book:

Author(s), "Title of Paper," in Computer Vision and Image Analysis of Art II, edited by David G. Stork, Jim Coddington, Anna Bentkowska-Kafel, SPIE-IS\&T Electronic Imaging, Vol. 7869 (SPIE, Bellingham, WA, 2011) Article CID Number.

ISSN 0277-786X

ISBN 9780819484062

Copublished by

SPIE

P.O. Box 10, Bellingham, Washington $98227-0010$ USA

Telephone +1 3606763290 (Pacific Time) · Fax +13606471445

SPIE.org

and

IS\&T-The Society for Imaging Science and Technology

7003 Kilworth Lane, Springfield, Virginia, 22151 USA

Telephone +1 7036429090 (Eastern Time) · Fax +17036429094

imaging.org

Copyright (c) 2011, Society of Photo-Optical Instrumentation Engineers and The Society for Imaging Science and Technology

Copying of material in this book for internal or personal use, or for the internal or personal use of specific clients, beyond the fair use provisions granted by the U.S. Copyright Law is authorized by SPIE subject to payment of copying fees. The Transactional Reporting Service base fee for this volume is $\$ 18.00$ per article (or portion thereof), which should be paid directly to the Copyright Clearance Center (CCC), 222 Rosewood Drive, Danvers, MA 01923. Payment may also be made electronically through CCC Online at copyright.com. Other copying for republication, resale, advertising or promotion, or any form of systematic or multiple reproduction of any material in this book is prohibited except with permission in writing from the publisher. The CCC fee code is $0277-786 \mathrm{X} / 11 / \$ 18.00$.

Printed in the United States of America.

Publication of record for individual papers is online in the SPIE Digital Library.

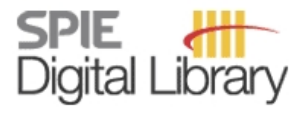

SPIEDigitalLibrary.org

Paper Numbering: Proceedings of SPIE follow an e-First publication model, with papers published first online and then in print and on CD-ROM. Papers are published as they are submitted and meet publication criteria. A unique, consistent, permanent citation identifier (CID) number is assigned to each article at the time of the first publication. Utilization of CIDs allows articles to be fully citable as soon they are published online, and connects the same identifier to all online, print, and electronic versions of the publication. SPIE uses a six-digit CID article numbering system in which:

- The first four digits correspond to the SPIE volume number.

- The last two digits indicate publication order within the volume using a Base 36 numbering system employing both numerals and letters. These two-number sets start with $00,01,02,03,04$, $05,06,07,08,09,0 A, 0 B \ldots$. 0Z, followed by 10-1Z, 20-2Z, etc.

The CID number appears on each page of the manuscript. The complete citation is used on the first page, and an abbreviated version on subsequent pages. Numbers in the index correspond to the last two digits of the six-digit CID number. 


\section{Contents}

vii Conference Committee
ix Introduction

SESSION 1 LOOKING INSIDE THE PAINTING

786903 Computer analysis of lighting style in fine art: steps towards inter-artist studies [7869-02]

D. G. Stork, Ricoh Innovations, Inc. (United States)

\section{SESSION 2 SEMANTIC CLASSIFICATIONS, ICONOGRAPHY, AND CBIR}

786904 The automatic annotation and retrieval of digital images of prints and tile panels using network link analysis algorithms [7869-03]

G. Carneiro, J. P. Costeira, Univ. Técnica de Lisboa (Portugal)

786905 Explaining scene composition using kinematic chains of humans: application to Portuguese tiles history [7869-04]

N. P. da Silva, M. Marques, G. Carneiro, J. P. Costeira, Univ. Técnica de Lisboa (Portugal)

786906 Top-down analysis of low-level object relatedness leading to semantic understanding of medieval image collections [7869-05]

P. Yarlagadda, A. Monroy, B. Carque, B. Ommer, Univ. of Heidelberg (Germany)

786907 A framework for analysis of large database of old art paintings [7869-06]

J. Da Rugna, G. Chareyron, Pôle Univ. Lonard de Vinci (France); R. Pillay, M. Joly, C2RMF

(France)

\section{SESSION 3 IMAGE ACQUISITION AND PROCESSING}

786908 Image fusion for art analysis [7869-07]

B. Zitová, Institute of Information Theory and Automation (Czech Republic); M. Beneš, J. Blažek, Institute of Information Theory and Automation (Czech Republic) and Charles Univ. (Czech Republic)

786909 Recovery of handwritten text from the diaries and papers of David Livingstone [7869-08] K. T. Knox, Air Force Research Lab. (United States); R. L. Easton, Jr., Rochester Institute of Technology (United States); W. A. Christens-Barry, Equipoise Imaging, LLC (United States); K. Boydston, Megavision Inc. (United States)

7869 OA Automation of digital historical map analyses [7869-09]

T. W. Shaw, P. Bajcsy, Univ. of Illinois at Urbana-Champaign (United States)

$7869 \mathrm{OB}$ Automatic multispectral ultraviolet, visible and near-infrared capturing system for the study of artwork [7869-16]

J. Herrera, M. Vilaseca, J. Pujol, Technical Univ. of Catalonia (Spain) 
7869 OC Towards automatic registration of technical images of works of art [7869-11]

D. M. Conover, The George Washington Univ. (United States); J. K. Delaney, P. Ricciardi, National Gallery of Art (United States); M. H. Loew, The George Washington Univ. (United States)

7869 OD Art documentation quality in function of 3D scanning resolution and precision [7869-12] E. Bunsch, Museum Palace at Wilanow (Poland); R. Sitnik, J. Michoński, Warsaw Univ. of Technology (Poland)

7869 OE Investigation of the degradation mechanism and discoloration of traditional Japanese pigments by multispectral imaging [7869-13]

J. A. Toque, A. Ide-Ektessabi, Kyoto Univ. (Japan)

7869 OF Improved methods for dewarping images in convex mirrors in fine art: applications to van Eyck and Parmigianino [7869-14]

Y. Usami, Waseda Univ. (Japan); D. G. Stork, Ricoh Innovations, Inc. (United States); J. Fujiki, National Institute of Advanced Industrial Science and Technology (Japan); H. Hino, Waseda Univ. (Japan); S. Akaho, National Institute of Advanced Industrial Science and Technology (Japan); N. Murata, Waseda Univ. (Japan)

\section{INTERACTIVE PAPER SESSION}

7869 OG Time and order estimation of paintings based on visual features and expert priors [7869-15] R. S. Cabral, Univ. Técnica de Lisboa (Portugal) and Carnegie Mellon Univ. (United States); J. P. Costeira, Univ. Técnica de Lisboa (Portugal); F. de La Torre, Carnegie Mellon Univ. (United States); A. Bernardino, G. Carneiro, Univ. Técnica de Lisboa (Portugal)

$7869 \mathrm{OH} \quad$ Boosting multi-feature visual texture classifiers for the authentication of Jackson Pollock's drip paintings [7869-17]

M. Al-Ayyoub, M. T. Irfan, Stony Brook Univ. (United States); D. G. Stork, Ricoh Innovations, Inc. (United States)

7869 ol Improved curvature-based inpainting applied to fine art: recovering van Gogh's partially hidden brush strokes [7869-18]

Y. Kuang, Lund Univ. (Sweden); D. G. Stork, Ricoh Innovations, Inc. (United States); F. Kahl, Lund Univ. (Sweden)

7869 0J Did Caravaggio employ optical projections? An image analysis of the parity in the artist's paintings [7869-19]

D. G. Stork, Ricoh Innovations, Inc. (United States)

7869 OK A computer graphics reconstruction and optical analysis of scale anomalies in Caravaggio's "Supper at Emmaus" [7869-20]

D. G. Stork, Ricoh Innovations, Inc. (United States); Y. Furuichi, Consultant (Japan)

7869 OL X-ray image analysis of Lorenzo Lotto's Husband and wife [7869-21]

D. G. Stork, Ricoh Innovations, Inc. (United States); A. J. Kossolapov, State Hermitage Museum (Russian Federation) 
7869 OM Automated classification of quilt photographs into crazy and non-crazy [7869-22] A. Gokhale, Indian Institute of Technology (India); P. Bajcsy, Univ. of Illinois at Urbana-Champaign (United States)

7869 ON Polarized light scanning for cultural heritage investigation [7869-23]

J. A. Toque, Y. Murayama, Y. Matsumoto, A. Ide-Ektessabi, Kyoto Univ. (Japan)

$786900 \quad$ After digital cleaning: visualization of the dirt layer [7869-24]

C. M. T. Palomero, M. N. Soriano, Univ. of the Philippines (Philippines)

Author Index 
Downloaded From: https://www.spiedigitallibrary.org/conference-proceedings-of-spie on 26 Apr 2023

Terms of Use: https://www.spiedigitallibrary.org/terms-of-use 


\title{
Conference Committee
}

\author{
Symposium Chair
}

Sabine E. Süsstrunk, École Polyłechnique Fédérale de Lausanne

(Switzerland)

Symposium Cochair

Majid Rabbani, Eastman Kodak Company (United States)

Conference Chairs

David G. Stork, Ricoh Innovations, Inc. (United States)

Jim Coddington, Museum of Modern Art (United States)

Anna Bentkowska-Kafel, King's College London (United Kingdom)

Program Committee

Ingrid Daubechies, Princeton University (United States)

Charles R. Dyer, University of Wisconsin-Madison (United States)

Roger L. Easton, Jr., Rochester Institute of Technology (United States)

Daniel J. Graham, Dartmouth College (United States)

Ella Hendriks, Van Gogh Museum (Netherlands)

Shannon M. Hughes, University of Colorado at Boulder (United States)

Mohammad Tanvir Irfan, Stony Brook University (United States)

Siwei Lyu, New York University at Albany (United States)

Kirk Martinez, University of Southampton (United Kingdom)

Eric O. Postma, University van Tilburg (Netherlands)

Daniel N. Rockmore, Dartmouth College (United States)

Robert Sablatnig, Technische Universität Wien (Austria)

Ron Spronk, Queen's University (Canada)

Filippo D. Stanco, Universita degli Studi di Catania (Italy)

David M. Stone, University of Delaware (United States)

Song-Chun Zhu, University of California, Los Angeles (United States)

Session Chairs

$1 \quad$ Looking Inside the Painting

Anna Bentkowska-Kafel, King's College London (United Kingdom)

2 Semantic Classifications, Iconography, and CBIR

Anna Bentkowska-Kafel, King's College London (United Kingdom) 
3 Image Acquisition and Processing

Anna Bentkowska-Kafel, King's College London (United Kingdom)

$4 \quad$ Visualization, Documentation, and Art Restoration

David G. Stork, Ricoh Innovations, Inc. (United States) 


\section{Introduction}

The technical conference Computer Vision and Image Analysis of Art II was part of the IS\&T/SPIE Electronic Imaging symposium, held in San Francisco, California, 25-26 January 2011. This was the third IS\&T/SPIE conference in this interdisciplinary field. The growing number of research collaborations and the breadth of topicsfrom capture, image processing and archiving to computer vision analysis, computer graphics simulations and scholarly interpretation-shows the field is providing value to the broader community of art scholars and museum professionals. Papers included in this volume demonstrate how reading of artifacts can be enhanced, and new data discovered, through application of imaging techniques; the recovery of handwritten text from the diaries and papers of the 19th-century explorer, David Livingstone, being an excellent example. Even when the results are less spectacular, or ambiguous, the value of such applications lies in how the new tools lead to an enhanced understanding of the material, both physical and intellectual, under investigation.

The keynote address, delivered by Ron Spronk, Professor of Art History at Queen's University, Canada, centered on the challenges in technical examination, restoration and re-interpretation of the Ghent Altarpiece by the Van Eyck brothers, one of the defining works of early Renaissance art of northern Europe. He described the painstaking multi-year restoration effort, and the role of highresolution multi-spectral imaging in documenting the effort and the work. Computer processing and enhancement of such images will be a tool for conservators, curators and art historians. In perhaps excessively general terms the use of pattern recognition, so fundamental to much image analysis, offers new ways of looking at not just single works but entire groups of works of art and to find new patterns within them.

If computer science is to continue to support art analysis, we must ensure that the insights gained benefit both disciplines. This can only happen if and when research questions are formulated through dialogue and collaboration. The lively discussion at the conference concerning the seemingly realistic space depicted in the Van Eycks' masterpiece Portrait of Giovanni (?) Arnolfini and his wife-seen by the scientists in physical and geometrical terms, and by the art historians in metaphysical, illusionistic terms-may serve as an illustration of common misunderstandings. While confirming that each discipline has its own discrete research methods and established conventions of intellectual inquiry, this example also shows that the challenge of successful interdisciplinary research lies in the readiness to step outside the inherited modes of operation and the comfort of one's own mind set. We need to learn the terms of the other discipline and embrace its 'language' and world views. 
The authors are grateful for the opportunity to present their research and have their papers published. We editors hope these proceedings will stimulate discussion and new collaborations between scholars in computer science and the arts. We would like to thank all the contributors, reviewers, attendees, and the staff of IS\&T/SPIE for making the conference a success. It has been particularly satisfying to have the participation of leading experts in the field alongside young researchers presenting their first conference paper or poster ever. We hope they all have found the conference a stimulating experience and were able to establish new contacts. We are especially glad that IS\&T/SPIE recognizes the value of the interdisciplinary research that appears in this volume, and supports next year's conference.

\section{David G. Stork Jim Coddington Anna Bentkowska-Kafel}

